\title{
9. A GEOPHYSICAL SURVEY AT SITE 325 IN THE BELLINGSHAUSEN BASIN ${ }^{1}$
}

\author{
Fred W. Schroeder, ${ }^{2}$ Lamont-Doherty Geological Observatory of Columbia University, Palisades, New York
}

\begin{abstract}
In the vicinity of DSDP Site 325 , a detailed site survey shows a general northeast trend in topography and a buried fracture zone striking perpendicular to the topography. Four topographic highs are present in the northeast section of the survey area and may be related to the proposed fracture zone.The topography slopes gently to the northwest away from the Antarctic Peninsula and results from a decrease in sediment thickness to the northwest. The basement is relatively horizontal northeast of the fracture zone and rugged to the southwest. Magnetic lineations trend parallel to the topography, and displacement of the anomaly pattern indicates the presence of the fracture zone.
\end{abstract}

\section{INTRODUCTION}

A detailed marine geophysical survey was conducted in the Bellingshausen Basin on R/V Conrad cruise 15 during December 1971 (Figure 1). The survey was done in preparation for Leg 35 of the Deep Sea Drilling Project. This site was chosen on the basis of earlier reconnaissance work carried out on the U.S.N.S. Eltanin on cruise 43 during April and May 1970. The navigational data for both cruises are presented in Figure 2.

The survey area lies on the Antarctic continental rise between the continental slope and the Bellingshausen Abyssal Plain. The inferred direction of sediment dispersal is north from Antarctica, and the sediment distribution is probably controlled by a combination of turbidity currents, ice-rafting, and bottom currents (Ewing et al., 1968).

\section{TOPOGRAPHY}

The relief across the survey area is 350 meters except for four topographic highs with crests at 3200,1625 , 1750 , and 3625 meters (Figure 3). The sea floor deepens northwestward with a regional gradient of approximately $1: 500$. The sea floor is relatively smooth over most of the region except where the basement rises close to or above the sediment surface and produces a bottom roughness. Channels cut across the sediment surface and appear to be distributary channels for turbidity currents flowing off the Antarctic slope and upper rise.

\section{SEISMIC REFLECTION AND REFRACTION}

Seismic profiler records show a sediment cover of up to $1.3 \mathrm{sec}$ reflection time (Figures 4 and 5). Acoustic basement has moderate to high reflectivity and varies in morphology from rugged peaks typical of Layer 2 to an anomalously smooth basement reflector (Houtz, 1974).

\footnotetext{
'Lamont-Doherty Geological Observatory Contribution 2138.

${ }^{2}$ Department of Geological Sciences, Columbia University, N.Y., N.Y.
}

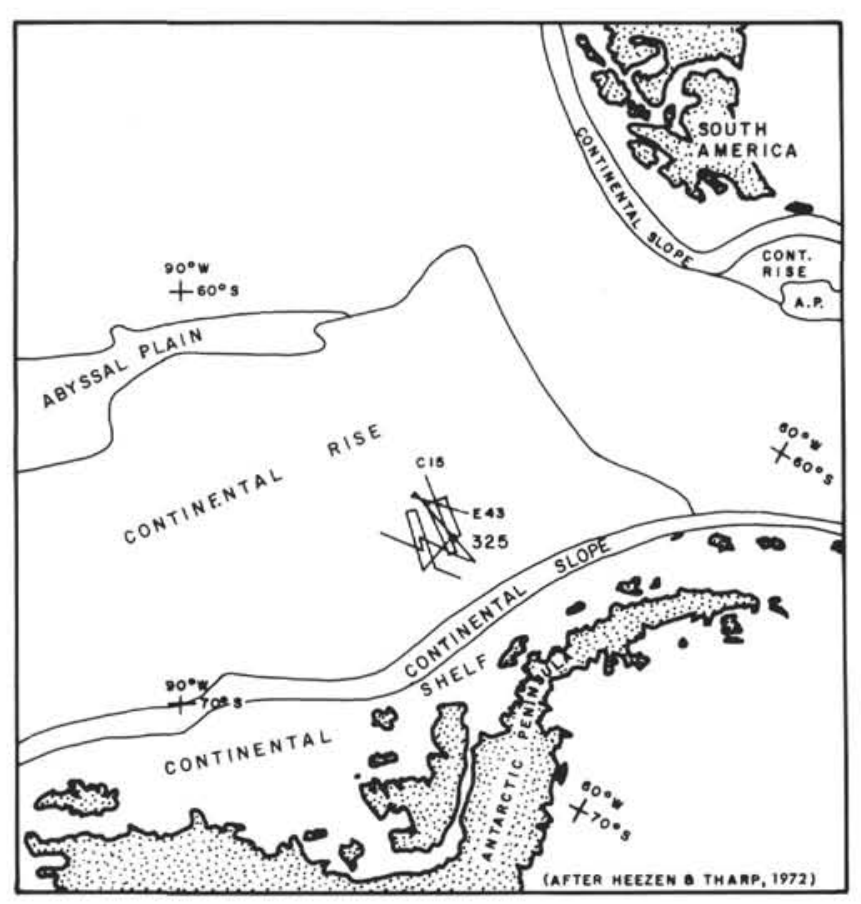

Figure 1. Physiographic map of the eastern Bellingshausen Basin showing the area of the survey for Site 325. The tracks of R/V Robert Conrad and U.S.N.S. Eltanin in the survey area are shown.

The sediment column is characterized by two major acoustic units. The upper unit characteristically contains many closely spaced reflectors and locally appears to lie unconformably on the second unit. The second unit consists of a transparent zone, often with a distinct reflector at the top. All the seismic reflection profiles within and adjacent to the site survey area are presented in Figures $\mathrm{A} 1, \mathrm{~A} 2$, and $\mathrm{A} 3$.

Sonobuoy $\mathrm{RC} 15-13$ was recorded at $64^{\circ} 58^{\prime} \mathrm{S}$ and $73^{\circ} 29^{\prime} \mathrm{W}$ near Site 325 . Analysis of the wide-angle reflections indicates that the upper acoustic unit has an interval velocity of $2.04 \pm 0.10 \mathrm{~km} / \mathrm{sec}$ and a thickness of 0.35 


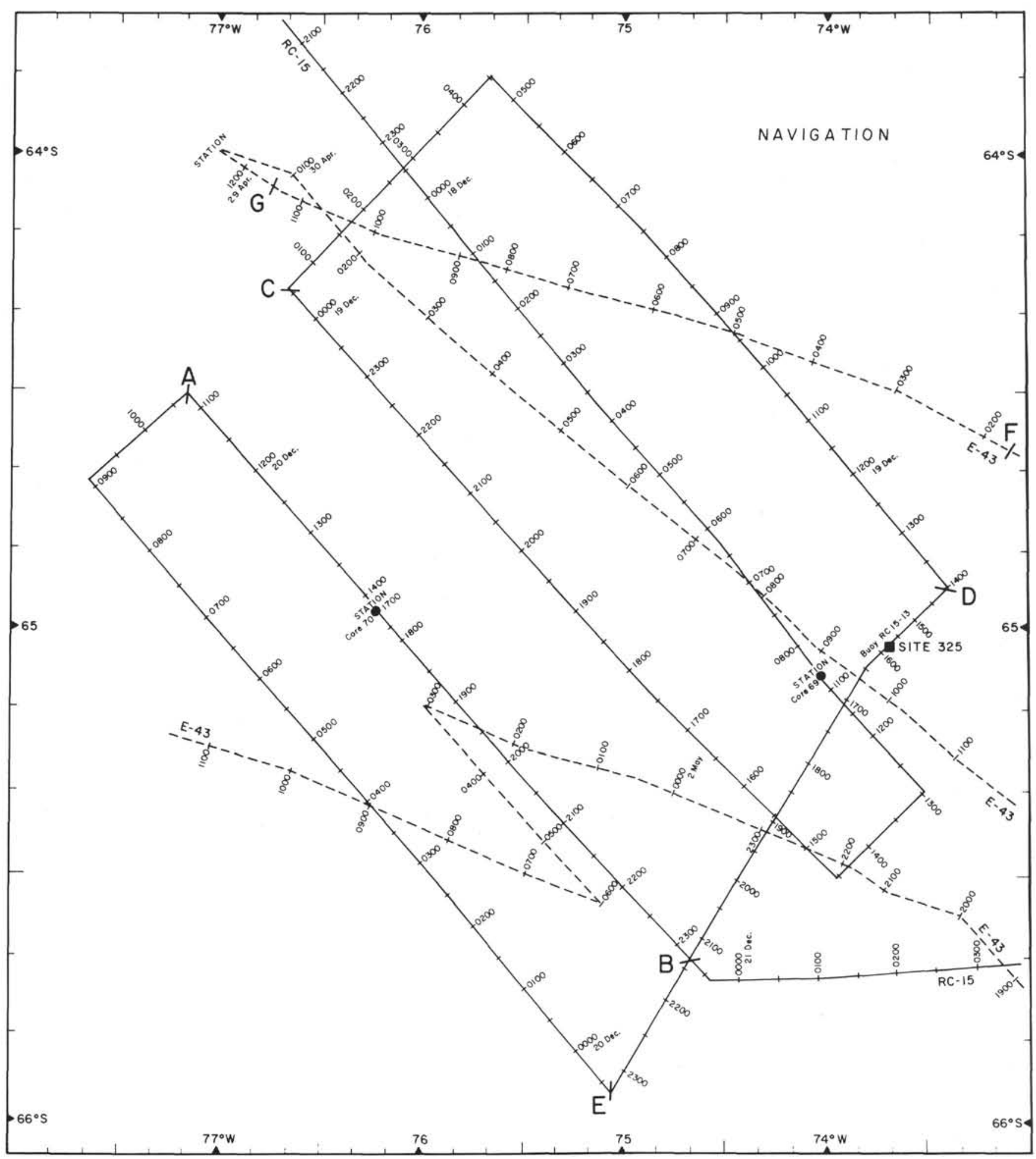

Figure 2. Navigational data in the survey area. Included are the days and hours along the tracks, and locations of the cores, sonobuoy, and profiles shown in Figure 4.

$\mathrm{km}$. The second acoustic unit has an interval velocity of $2.82 \pm 0.09 \mathrm{~km} / \mathrm{sec}$ and a thickness of $0.87 \mathrm{~km}$. Refraction arrivals also indicate an apparent velocity of 5.35 $\mathrm{km} / \mathrm{sec}$ for acoustic basement, which compares well with an average value of $5.07 \pm 0.63 \mathrm{~km} / \mathrm{sec}$ for Layer 2 for all ocean basins (Raitt, 1963). The calculated thickness of Layer 2 is $0.92 \mathrm{~km}$. The apparent velocity for the oceanic layer is $6.65 \mathrm{~km} / \mathrm{sec}$ and compares well with an average value of $6.69 \pm 0.26 \mathrm{~km} / \mathrm{sec}$ for all ocean basins (Raitt, 1963). (See also Tucholke and Edgar, this volume, for a comparison of acoustic stratigraphy and lithology.) 


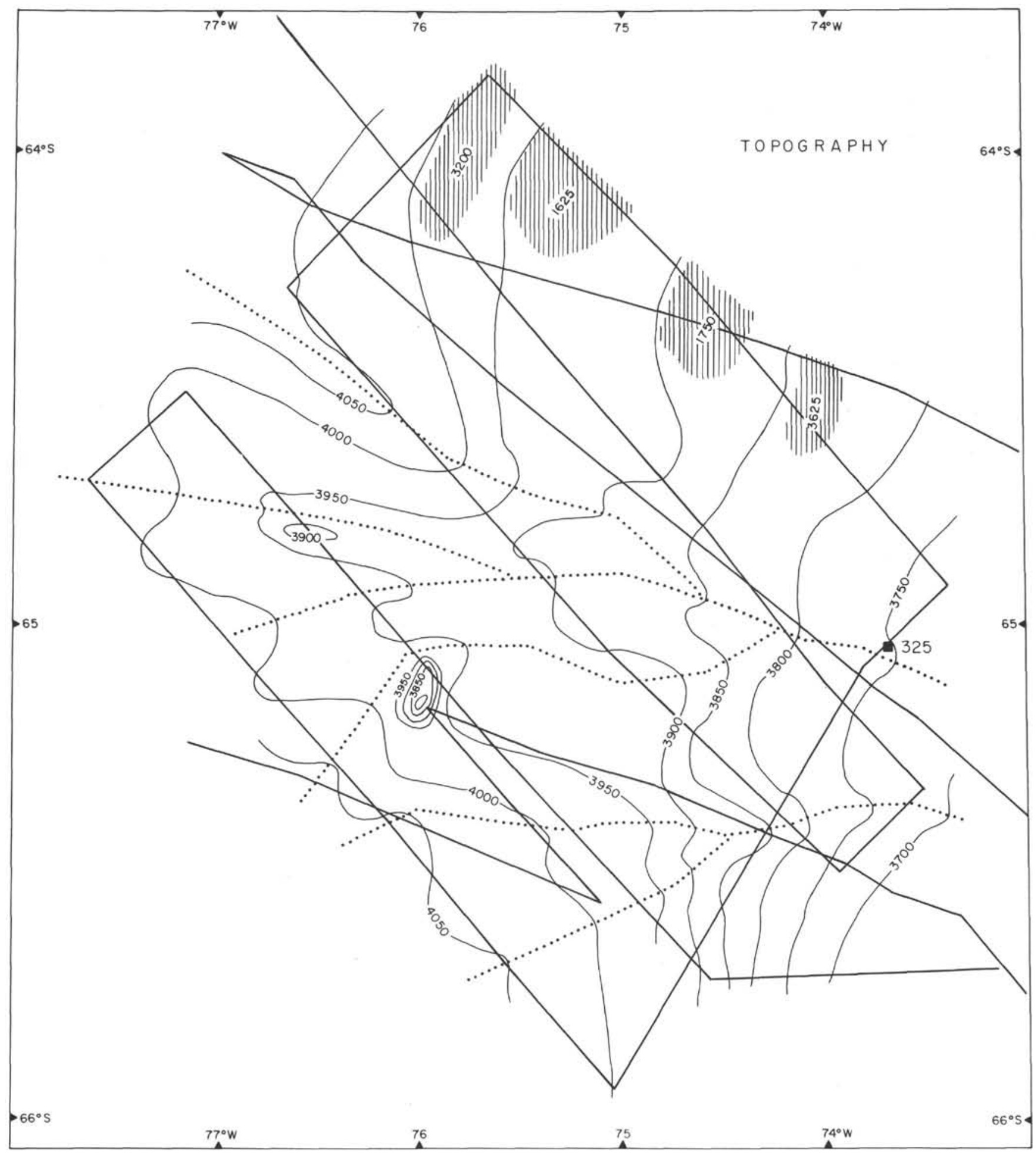

Figure 3. Bathymetric map of the survey area in corrected meters. The four topographic highs are indicated by crosshatching and peak values alone are given. The dotted lines represent the axes of distributary channels.

The $3.5-\mathrm{kHz}$ PDR records show channels in the sediment surface which have probably been maintained by turbidity currents flowing down the Antarctic continental slope and rise. One large channel, which was crossed to the east of the survey area and higher on the rise (see profiles in Appendix Figures A2 and A3 RC15 at 0330 on 21 December and ELT43 at 2000 on 28 April), may be the main channel feeding the distributary channels that cut across the survey area (Figure 3 ). These distributary channels are shallow $(60 \mathrm{~m})$ to deep $(300 \mathrm{~m})$ depressions in the sea floor, often with hyperbolic echo returns from their walls. Bordering levees are oc- 
A

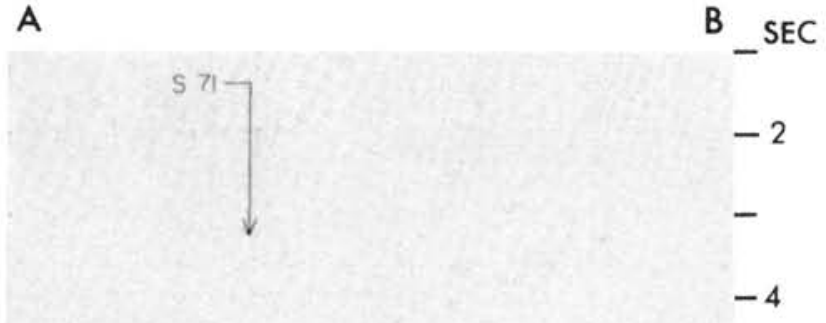

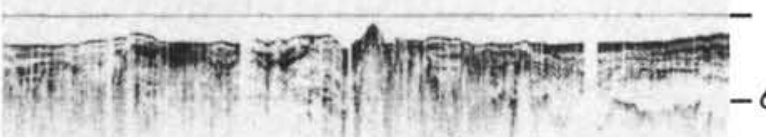

$\begin{array}{llllllllll}1 & 1 & 1 & 1 & 1 & 1 & 1 & 1 & 1 & 1 \\ 12 & & 14 & 17 & & & 20 & & & 23\end{array}$ 20 Dec. ' 71

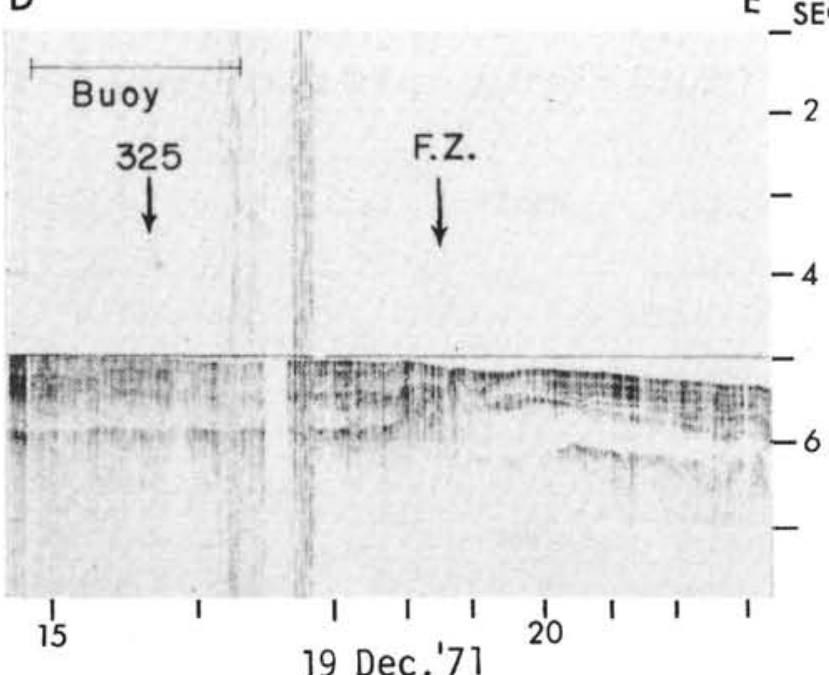

C

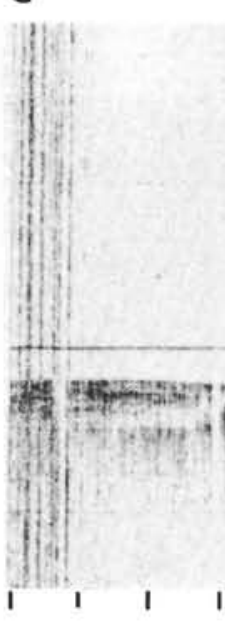

'́s

19 Dec.'71

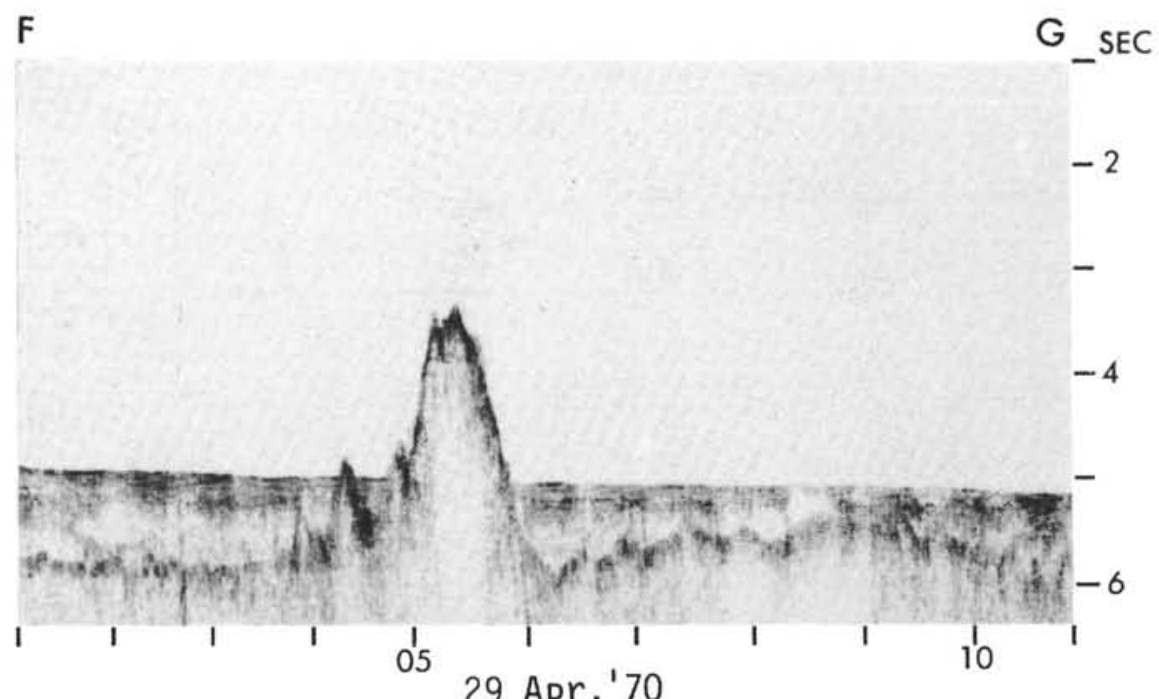

29 Apr.' 70

Figure 4. Seismic reflection profiles in the survey area (see Figure 2 for location). $C / C$ indicates a course change. Profile A-B shows the thickening of the sediment towards Antarctica and the rough basement. Profile C-D shows the four topographic highs and the smooth basement. Profile D-E passes over Site 325 at hour 15:45. Sonobuoy RC15-13 was shot on this traverse from 14:40 to 16:30. The fracture is crossed at 18:30 where basement morphology changes to one of greater relief. 


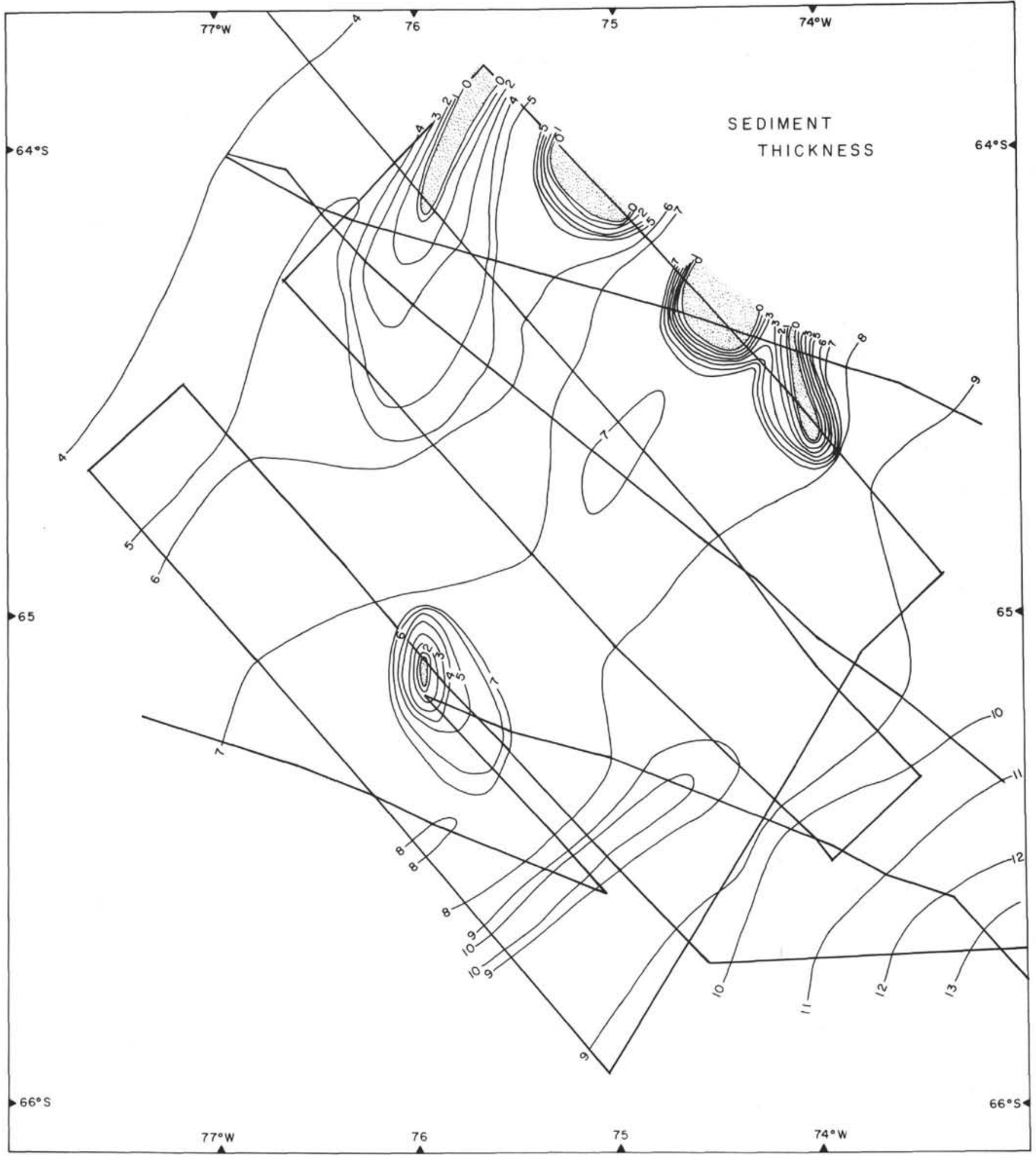

Figure 5. Isopach map of sediment thickness in the survey area. Contour interval is 1/10 sec reflection time. The stippled areas indicate no sediment cover detectable in seismic profiler records.

casionally observed, also producing hyperbolic returns. The channel floor varies from flat with horizontal reflectors (probably turbidites) to irregular with numerous hyperbolae. In the latter case, hyperbolae may be related to turbidity current erosion or to slumped sediments within the channel. Many of the channels have a thin $(20-60 \mathrm{~m})$ conformable cover of sediment which suggests they are presently inactive.

Two types of echo characteristics are observed in the $3.5-\mathrm{kHz}$ records. The first is characterized by a thin, 
sharp surface reflector overlying a zone of thin, conformable subsurface reflectors. The surface reflector is separated from the subsurface reflectors by about 10-15 meters of acoustically transparent material. This type of echo character is found in the northern and western sections and in the southeast corner of the survey area and is interpreted to represent deposition of hemipelagic sediment with little reworking by bottom currents.

The second type of echo has only a diffuse surface reflector and shows no subbottom penetration. This bottom corrugation is thought to represent erosion and redeposition of sediment by bottom currents. Westward flow of contour-following bottom currents in this area was postulated by Hollister and Heezen (1967) from bottom photographs and potential temperature data. Hyperbolic echoes are common near the topographic highs in the eastern part of the survey area, and they may be related to intensified current flow around these obstacles. The currents flow south and southwest from the topographic highs through the center of the survey area and align themselves parallel to the bathymetric contours, as determined by the distribution of the second type of echo.

\section{MAGNETICS}

There are well-defined magnetic lineations running northeast-southwest in the survey area (Figures 6 and 7). Magnetic anomalies 6c to 12 (after Heirtzler et al., 1968) have been identified (Herron and Tucholke, this volume) and are indicated in Figure 7. The pattern of younger anomalies toward the southeast suggests that the spreading center which created the crust at Site 325 has been subducted beneath Antarctica.

A fracture zone striking northwest through the center of the region is indicated by an offset in the magnetic pattern (Figure 6). The offset in crustal age is approximately 3 million years. A fracture zone is also indicated by differing basement morphologies on either side. The basement to the northeast of the fracture zone is relatively smooth, whereas to the southwest it is very rugged with higher relief. The difference is best illustrated in a comparison of Profile A-B, with rugged basement, and Profile C-D which shows the smoother basement between the topographic highs. The fracture is crossed on Profile D-E where the basement changes abruptly at $1830 \mathrm{hr}$.

\section{PISTON CORES}

The location of two piston cores taken in the survey area is shown in Figure 2. Core RC15-69, taken in a water depth of 3771 meters, recovered $663 \mathrm{~cm}$ of sediment from a hyperbolated levee on the southern side of a channel. The down-core lithology consists of: a top layer of clay $(172 \mathrm{~cm})$ with laminae of silt throughout and a 3-cm layer of silt at $85-88 \mathrm{~cm}$; a foram clay layer $(68 \mathrm{~cm})$ with a $10 \%$ coarse fraction $(>63 \mu \mathrm{m})$; and 423 $\mathrm{cm}$ of clay with silt laminae at the base. The coarse fraction includes quartz fragments, opaque minerals, volcanic glass, acidic and basic rock fragments, and mica. Foraminifera and echinoid spines comprise the biogenic component of the sediment.

Core RC15-70 was obtained in a water depth of 3981 meters and recovered $1017 \mathrm{~cm}$ of sediment from within a probable channel axis. The sediment consists of: a $23-\mathrm{cm}$ surface layer of clay; $7 \mathrm{~cm}$ of sandy silt $(20 \%>63 \mu \mathrm{m}) ; 43$ $\mathrm{cm}$ of clay; $77 \mathrm{~cm}$ of foram clay ooze ( $45 \%$ coarse fraction); $822 \mathrm{~cm}$ of interbedded clay and sandy silt similar to the top $30 \mathrm{~cm} ; 17 \mathrm{~cm}$ of sand (85\% coarse fraction); and $28 \mathrm{~cm}$ of clay and foram ooze at the bottom of the core. The coarse fraction $(>63 \mu \mathrm{m})$ contains: quartz, opaque minerals, igneous, metamorphic and sedimentary rock fragments, olivine, and amphibole. The biogenic component includes planktonic foraminifera, radiolarians, and minor amounts of benthonic foraminifera. The sand and sandy silt layers appear to be turbidites as indicated by the large coarse fraction and occasional grading. Activity within the channel appears to have been intermittent, resulting in the alternate deposition of sandy silt and clay. The presence of a surface layer of clay indicates recent inactivity.

\section{CONCLUSIONS}

1. A general northeast-southwest trend in the topography and the presence of distributory channels are indicated. Data from piston cores and $3.5-\mathrm{kHz}$ records suggest that the channels are presently inactive.

2. Magnetic anomalies suggest that a spreading center has been subducted beneath the Antarctic continental margin to the southeast of the survey area.

3. A fracture zone striking northwest-southeast is indicated by an offset in magnetic anomalies and a change in morphology of the basement.

4. Sonobuoy RC15-13, taken within $1 \mathrm{~km}$ of Site 325, shows two sedimentary acoustic units with velocities of $2.04 \mathrm{~km} / \mathrm{sec}$ and $2.82 \mathrm{~km} / \mathrm{sec}$ over a basement with a velocity of $5.35 \mathrm{~km} / \mathrm{sec}$ and an oceanic layer of 6.65 $\mathrm{km} / \mathrm{sec}$.

5. The sedimentation patterns indicate an alternation of deposition and erosion by turbidity currents flowing down distributary channels with a pelagic deposition of clay. Superimposed on this pattern are the effects of westward-flowing contour-following currents which erode and redeposit sediment.

\section{ACKNOWLEDGMENTS}

This work was supported by the National Science Foundation under Grant GA 28338.

I thank Stephen Eittreim and Ellen Herron for their aid in the preparation of the data. I am grateful to Mr. John I. Ewing for his guidance throughout this work and to Brian Tucholke for his many helpful discussions. Criticism of this paper by Robert Embley, Brian Tucholke, and Robert Houtz is gratefully acknowledged. B. Batchelder drafted the figures and B. Hautau typed the manuscript.

\section{REFERENCES}

Ewing, M., Ewing, J., Houtz, R., and Leyden, R., 1968. Sediment distribution in the Bellinghausen Basin. In Symp. Antarctic Oceanogr., Sept. 13-16, 1966, Cambridge (Scott Polar Res. Inst.), Santiago, Chile: p. 89-99.

Heezen, B.C. and Tharp, M., 1972. Physiographic and tectonic provinces. In Heezen, B.C., Tharp, M., and Bentley, C.R. (Eds.), Morphology of the earth in the Antarctic and Subantarctic, Folio 1b, Antarctic Map Folio Series, American Geographical Society, New York, Plate 3.

Heirtzler, J.R., Dickson, G.O., Herron, E.M., Pitman, W.C., III, and Le Pichon, X., 1968. Marine magnetic anomalies, 


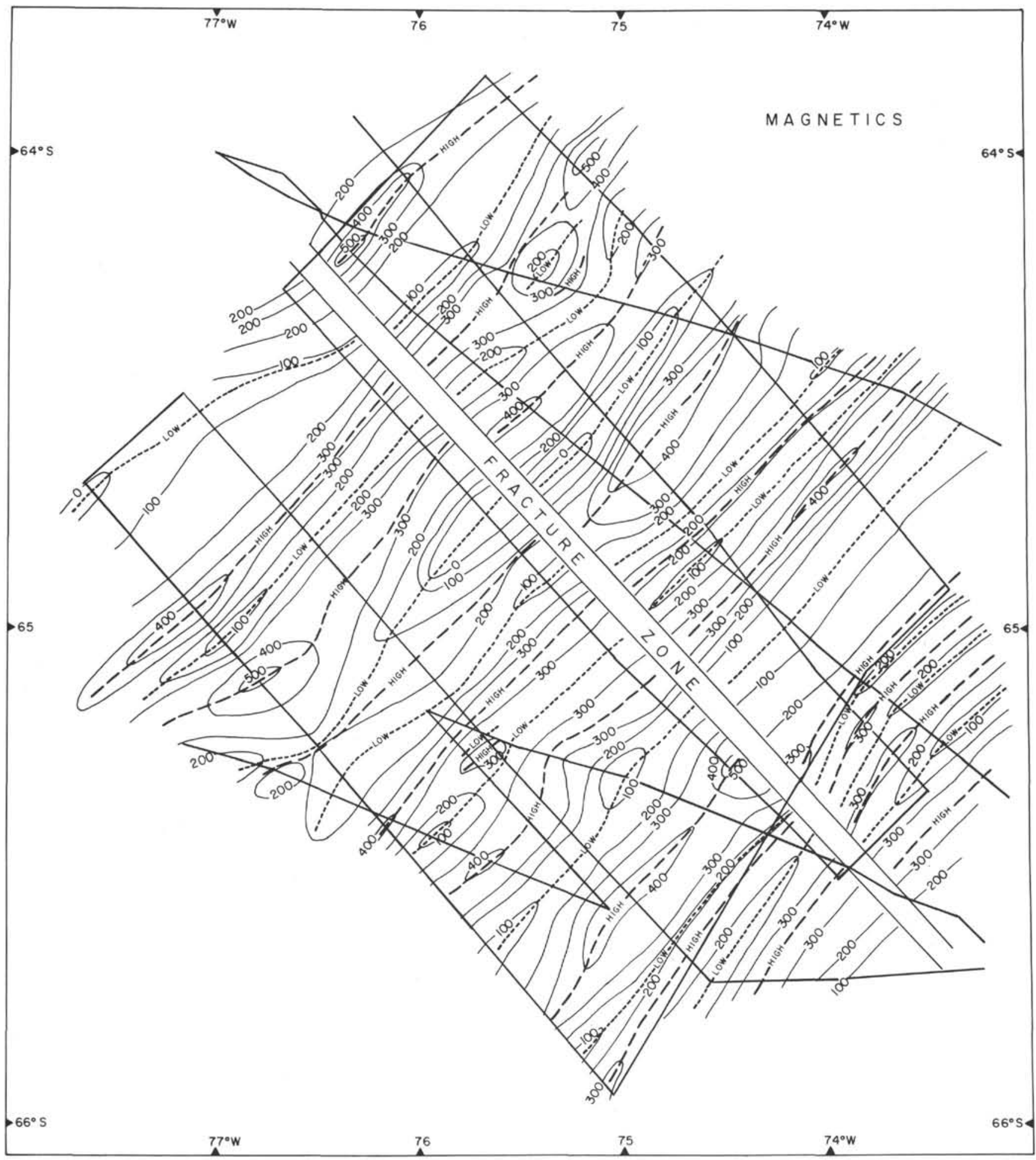

Figure 6. Map of residual magnetic intensity for the survey area. The contour interval is 100 gammas and highs and lows are correlated with dashed lines. A fracture zone is indicated striking northwest.

geomagnetic field reversals, and motions of the ocean floor and continents: J. Geophys. Res., v. 73, p. 2119-2136.

Hollister, C.D. and Heezen, B.C., 1967. The floor of the Bellingshausen Sea. In Hersey, J.B. (Ed.), Deep sea photography: Baltimore (John Hopkins Press), p. 177-189.
Houtz, R., 1974. Continental margin of Antarctica: PacificIndian Sectors. In Burk, C.A. and Drake, C.L. (Eds.), Continental margins: New York (Springer Verlag), p. 655-658.

Raitt, R., 1963. The crustal rocks. In Hill, M.N. (Ed.), The sea: v. 3, New York (Interscience), p. 85-102. 


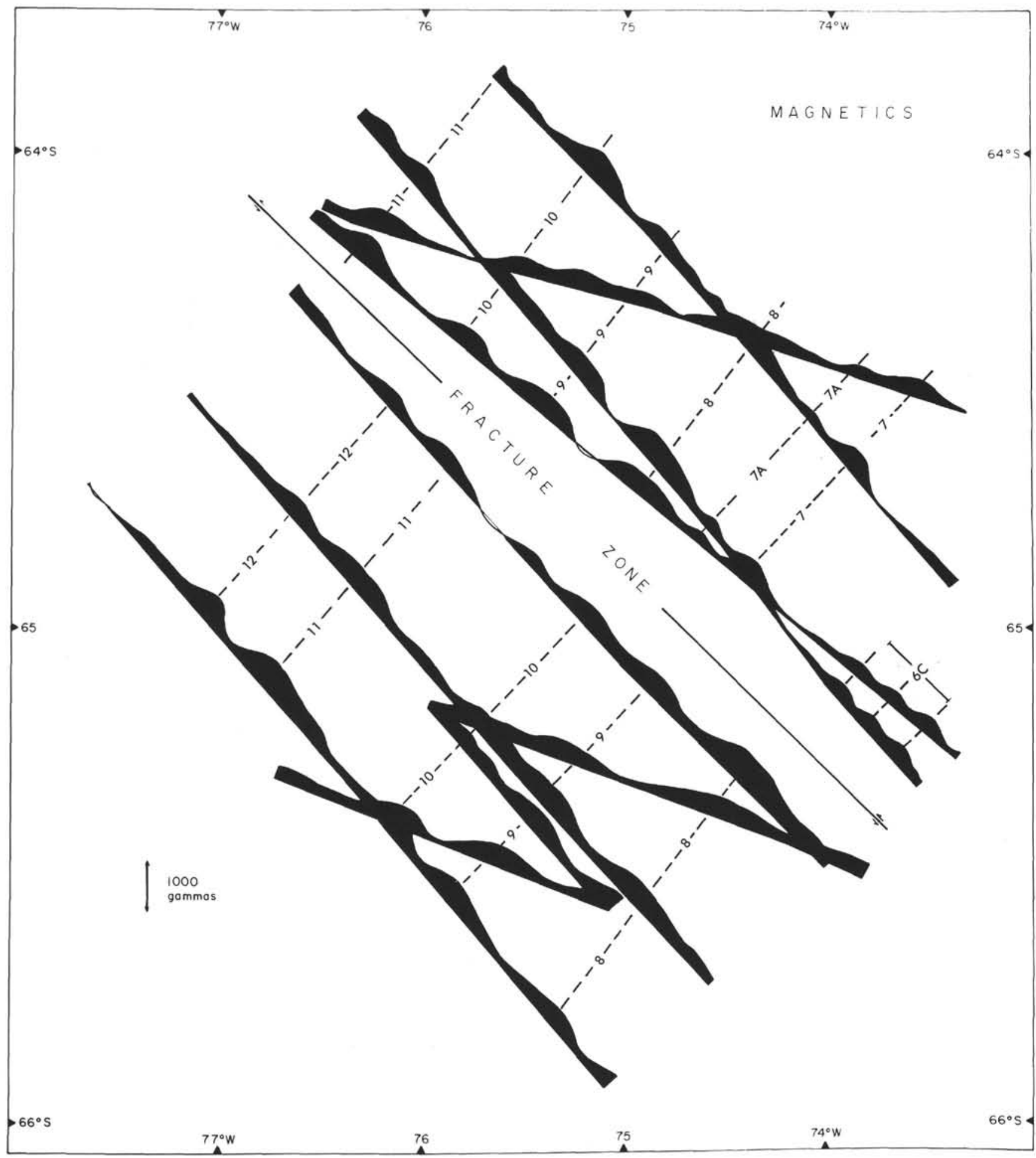

Figure 7. Magnetic intensity plotted along ship tracks in the survey area. Anomaly numbers are indicated and dashed lines show the correlation. A fracture zone is indicated. 

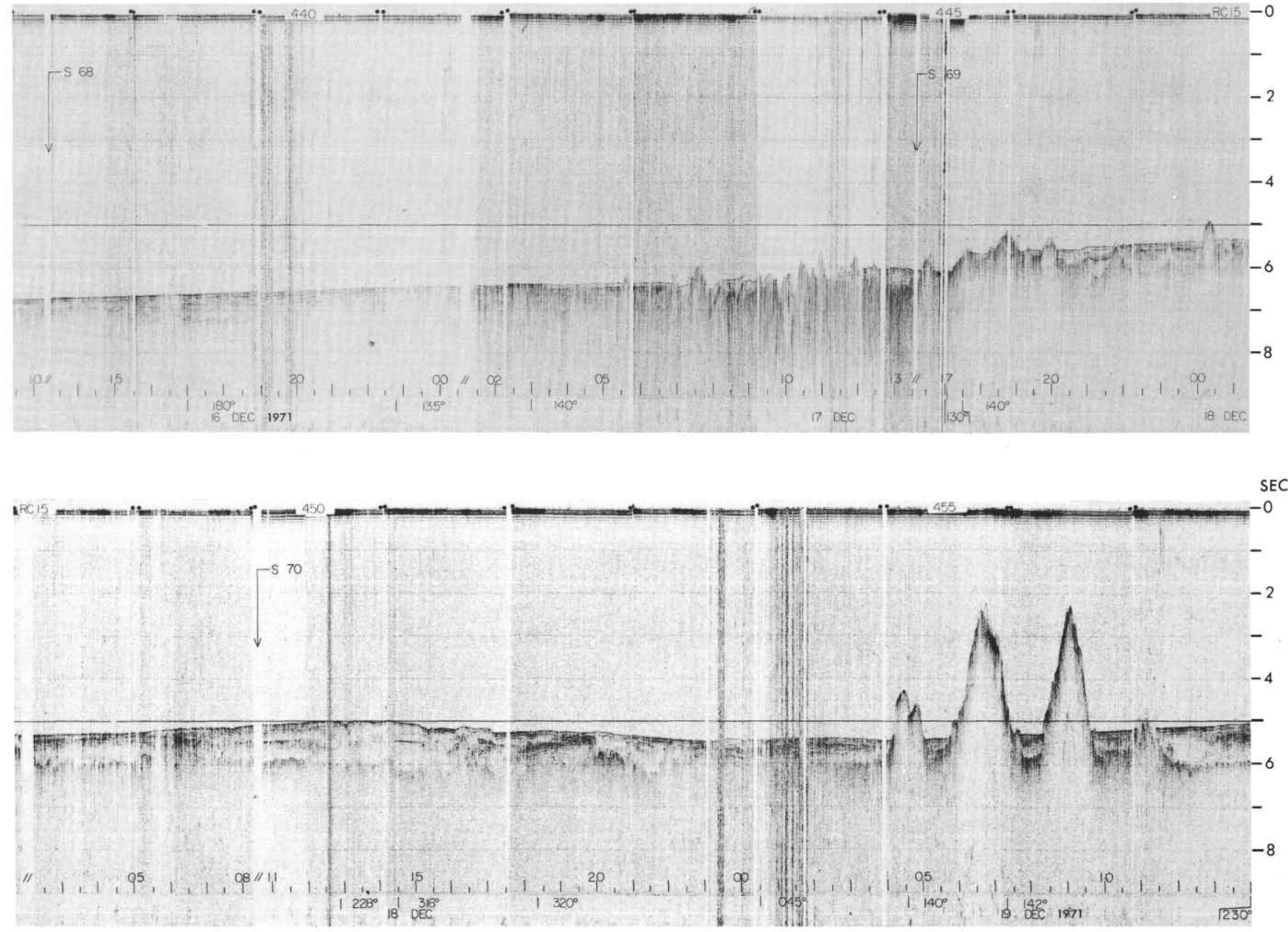

Figure A1. Conrad 15 seismic reflection profile (16-19 Dec., 1971) from site survey in the vicinity of Site 325. Day and hour marks correspond to those indicated on the track shown in Figure 2. 

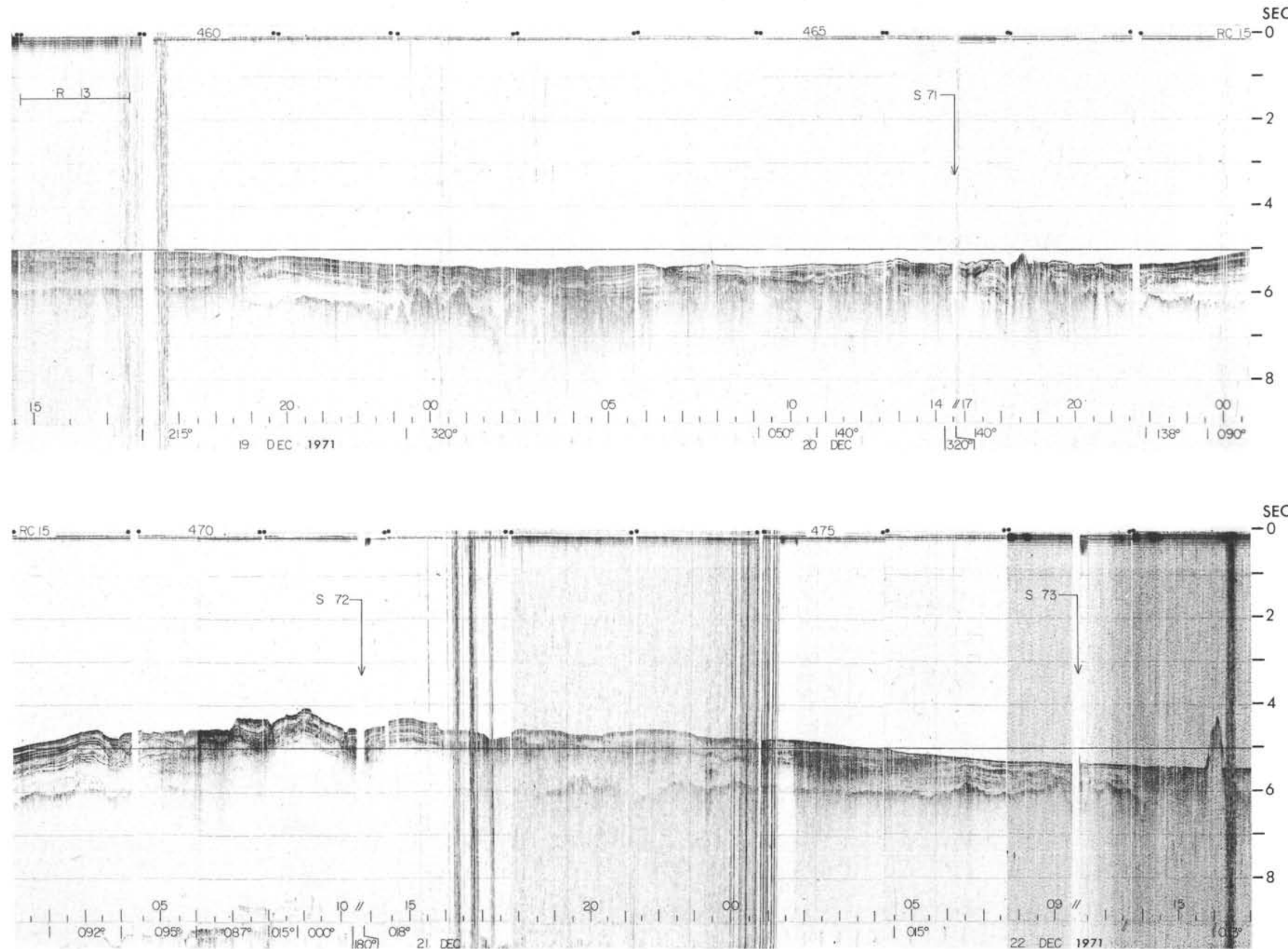

Figure A2. Conrad 15 seismic reflection profile (19-22 Dec., 1971) from site survey in the vicinity of Site 325. Day and hour marks correspond to those indicated on the track shown in Figure 2. 

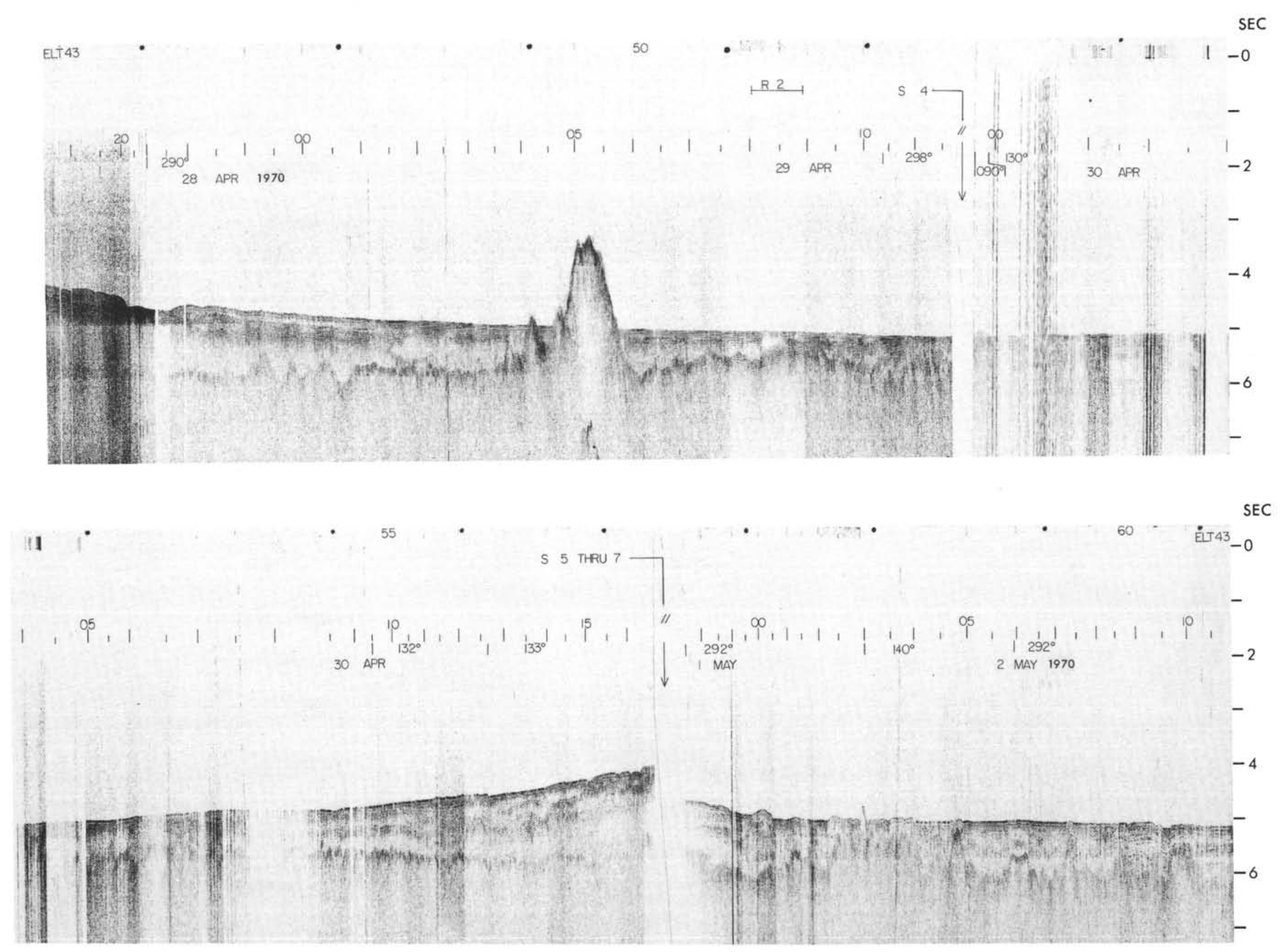

Figure A3. Eltanin 43 seismic reflection profile from site survey in the vicinity of Site 325. Day and hour marks correspond to those indicated on the track shown in Figure 2. 